This item was submitted to Loughborough's Research Repository by the author.

Items in Figshare are protected by copyright, with all rights reserved, unless otherwise indicated.

\title{
Party campaigners or citizen campaigners? How social media deepen and broaden party-related engagement
}

PLEASE CITE THE PUBLISHED VERSION

https://doi.org/10.1177/1940161216642152

\section{PUBLISHER}

Sage () The Author(s)

\section{VERSION}

AM (Accepted Manuscript)

\section{PUBLISHER STATEMENT}

This work is made available according to the conditions of the Creative Commons Attribution-NonCommercialNoDerivatives 4.0 International (CC BY-NC-ND 4.0) licence. Full details of this licence are available at: https://creativecommons.org/licenses/by-nc-nd/4.0/

\section{LICENCE}

CC BY-NC-ND 4.0

\section{REPOSITORY RECORD}

Vaccari, Cristian, and Augusto Valeriani. 2019. "Party Campaigners or Citizen Campaigners? How Social Media Deepen and Broaden Party-related Engagement”. figshare. https://hdl.handle.net/2134/28257. 


\section{Party campaigners or citizen campaigners?}

\section{How social media deepen and broaden party-related engagement}

\section{Cristian Vaccari}

Royal Holloway, University of London and University of Bologna

\section{Augusto Valeriani}

University of Bologna

\section{Abstract}

Digital media are often blamed for accelerating the decline of political parties as channels for citizen participation. By contrast, we show that political engagement on social media may revitalize party activities because these platforms are a means for both party members and ordinary citizens to discuss politics and engage with and around political parties. Using online surveys conducted in Germany, Italy, and the United Kingdom, we find that party members engage in a wider variety of party-related activities than average respondents, but the same can also be said of non-party members who informally discuss politics on social media. Moreover, the strength of the relationship between party membership and engagement decreases as the intensity of political discussion on social media increases. This suggests that political discussions on social media can narrow the divide in party-related engagement between members and nonmembers and to some extent flatten rather than reinforce existing political hierarchies. Finally, we find the correlation between party membership and engagement is stronger in Germany, where party organizations are more robust, than in Italy and the UK, highlighting the role of party organizational legacies in the digital age. 
Social media have become central hubs in contemporary flows of political communication across Western democracies. By contrast, political parties, one of the key institutions of representative democracy, are facing legitimacy and organizational crises. Eight-two percent of European Union citizens do not trust parties, while only $14 \%$ profess some confidence in them. ${ }^{1}$ Party membership has plummeted, inspiring somber assessments that "the party is over" (Whiteley 2011). Digital media have been touted as both the problem and the solution here. On the one hand, theorists of the so-called mobilization hypothesis contended that, under certain circumstances, the internet may favor political disintermediation: it would enable citizens to engage with specific issues, campaigns, and politicians on their own terms rather than via hierarchical organizations (Edwards 2006), and this would bring new people into contact with parties. Others, however, have suggested that, rather than encouraging new voices, the internet simply provides an additional participatory venue for those already active in traditional organizations, thus stifling rather than rejuvenating political activism (Norris 2003). The core empirical contention of this latter approach, which in the early days of internet politics research became known as the normalization hypothesis (Margolis and Resnick 2000), is that no substantial change has occurred both in the balance of power within and across political organizations and in the typical profile of those who participate.

The debate between supporters of mobilization (often referred to as "revolution") and normalization has been widely criticized for its straw-men arguments and poorly defined concepts. Scott Wright in particular has argued that researchers should abandon either/or approaches and be sensitive to the possibility of hybrid "normalized revolutions," where "new technologies create deeply significant, perhaps wholesale changes to the function of established political institutions without overthrowing those institutions." (Wright 2012: 253) This is particularly relevant when it comes to political parties. In spite of the need for a more 
nuanced approach, the idea that the internet simply reinforces political inequalities has become almost entrenched in the literature (Schlozman, Verba, and Brady 2010).

The evidence we present here suggests that reinforcement is not the only relevant outcome of citizens' political interactions on digital media. Instead, we show that informal political discussion deepens party-related engagement by offering new avenues by which party members can provide parties with support, feedback, and resources, and it broadens party-related engagement, by encouraging those who are not party members to get involved. We use online surveys of representative samples of internet users in Germany, Italy, and the United Kingdom in the aftermath of the 2014 European Parliament elections. These data show that while digital media cannot per se enhance political action among disengaged citizens they can provide avenues by which those who informally discuss politics on social media can find opportunities and incentives to engage with activities related and relevant to political parties. Political discussions on social media contribute to closing the gap in party-related engagement between members and non-members, to some degree flattening rather than reinforcing existing hierarchies. Thus, digital media are reconfiguring party-related engagement. This is a "hybrid" development of party activism in Chadwick's (2007) terms because it combines some features of the older concept of permanent membership with some newer features of what Rachel Gibson (2015) has termed "citizen-initiated campaigning".

\section{Party-Related Engagement Among and Beyond Party Members}

For the last three decades, political parties have faced sharp declines in their organizational strength and legitimacy, in spite of maintaining their institutional centrality in representative democracies (Mair 1995). Linkages between parties and voters have eroded, resulting in electoral dealignment (Dalton 1984), a hemorrhage of party members (Van Biezen et al. 2012), and declining voter turnout (Blais 2007). Some parties have met these challenges with 
three strategies: first, offering members process incentives such as primaries to select candidates and internal referenda on key policy decisions (Norris 2006); secondly, lowering the membership threshold, for instance by allowing online enrolment and offering the possibility to register as sympathizers rather than full-duty members (Scarrow 2015); thirdly, reviving voter mobilization efforts, especially in historically low-turnout countries such as the United States (Nielsen 2012) and the United Kingdom (Whiteley and Seyd 2003).

As a result of these developments, volunteers and sympathizers increasingly contribute to party activities without being permanently committed to them (Scarrow 2015), which in turn redefines what it means to be politically involved with and around a party. Such integration between different types of party activists has been noted not only in Europe, where most parties still carry the legacy of their mass-membership past, but also in the United States, where party organizations are more fluid and campaign-oriented than in Europe. Recent studies conceptualize American parties as "extended networks" or "long coalitions" that incorporate and bring together different types of elites, supporting organizations, and individual activists (Bawn et al. 2012). Heaney and Rojas (2015) argue that many of the participants in the post-9/11 anti-war movement identified and engaged with both the movement and the Democratic Party, and accordingly pursued "inside-outside" strategies combining party-style electoral mobilization with movement-style protest without necessarily depending on the party's formal structures. The hybridization of roles and repertoires of action between party insiders and outsiders resulted in what Heaney and Rojas (2015) call the "party in the street".

The media are generally understood to play important roles in selectively influencing different aspects of party membership and engagement. The first generation of research on the transformation and decline of party organizations mostly focused on the mass media, and television in particular, as potential drivers of change in the structure of incentives in party 
recruitment and activism (e.g. Kirchheimer 1966; Panebianco 1988). When digital media spread across Western democracies, a consensus emerged that the internet mostly served as a reinforcing mechanism for those activists who were already engaged with parties (Norris 2003) and that parties did not embrace the web to democratize their decision-making and decentralize their campaigning operations (Ward and Gibson 2009). As "Web 2.0" platforms diffused across Western democracies, parties maintained a cautious approach, establishing their presence on social media for fear of missing out but only partially embracing their potential for dialogue and engagement-resulting in what Jackson and Lilleker (2009) termed "Web 1.5" architectures of limited participation.

However, a second wave of theory and research emphasized that parties have much to gain from marshaling digitally enabled citizen engagement. Political discussion and engagement on social media is based on spontaneous, serendipitous, and lower-threshold practices which occur in informal interactions as part of citizens' everyday lives rather than in environments controlled by parties (Chadwick 2009; Vaccari et al. 2015). As a result, social media may provide opportunities for voters to engage with politics in less asymmetrical power relationships than earlier internet websites and party apparatuses. Embracing these changes, parties may develop a new organizational model, envisioned by Margetts, of "cyber parties," which "use web-based technologies to strengthen the relationship between voters and party rather than traditional notions of membership." (Margetts 2006: 530) In this new arrangement, parties may marshal what Gibson (2015) termed "citizen-initiated campaigning" by individuals who do not belong to the party staff but carry on some relevant electioneering activities for it through the web.

In this study, we assess how the web 2.0 can contribute to what we define as partyrelated engagement. By this we mean forms of political participation that allow parties to acquire resources, receive feedback, and distribute messages. The studies reviewed so far 
suggest that the web may contribute to party-related engagement in essentially two ways. First, by allowing existing party members to find new ways to engage in such activities, digital media may deepen party-related engagement among party members, equipping "party campaigners" with new tools to support their parties. Secondly, individuals who are not party members may find opportunities to engage with parties online as a result of the affordances of social media-in particular, the informality and spontaneity of political discussions that occur therein. In this case, social media in particular may broaden party-related engagement beyond party members, allowing "citizen campaigners" to play a greater role in the activities and organizational lives of parties.

As regards "party campaigners," research shows that members still fulfill vital functions for parties (Scarrow 2015) and the web enables such members to perform new activities that are integrated with existing offline practices, thus resulting in hybrid participatory repertoires (Chadwick 2007). The possibility that those who are already active within parties deepen their involvement by adding new tools to their campaigning arsenals has often been dismissed as irrelevant, at best constituting evidence of reinforcement (Norris 2003). However, these assessments overlook the fact that party activists can relay the information they find online to less interested individuals through interpersonal communication occurring both on the web and face-to-face. For instance, Norris and Curtice (2008) found that people who get election-related information on the internet are more likely to talk to others about it - a pattern that was confirmed by a comparative analysis of seven Western democracies (Vaccari 2013). Thus, party members can use digital media to act as conduits between parties and other citizens who are not directly contactable by parties (Gibson 2015). The internet also allows party members to provide input and feedback, which may boost organizational legitimacy by promoting reflexivity (Coleman 2005), and to contribute financial resources quickly, easily, and often in pursuit of specific goals. 
As regards "citizen campaigners", various studies suggest that political discussion and self-expression on social media may enhance engagement. Participation in political discussions on social media can expose individuals to relevant political information, which may motivate them to take further action (Kwak et al. 2005; Vaccari et al. 2015). Moreover, the non-political nature of social media may attract individuals who are not inclined to engage with political institutions (Wojcieszak and Mutz 2009), especially as they encounter "weak ties" that expose them to viewpoints they would not otherwise meet (Gil de Zúñiga and Valenzuela 2011) and accidentally encounter political information (Valeriani and Vaccari 2015). Thus, Rojas and Puig-i-Abril (2009) found that the more individuals express themselves politically through ICTs, the more they also attempt to mobilize others through social networking sites, which in turn translates into greater offline engagement. Gibson and Cantijoch (2013: 714) found that digital media may be leading to an "upgrading" of political discussion "into a more active participatory form" that pushes citizens up in the ladder of engagement. Relatedly, Gil de Zúñiga et al. (2014) show that political expression on social media mediates the effects of social media use on both online and offline political participation. As political discussion on social media is related to political participation, there is reason to believe that it should also be positively associated with party-related engagement.

Although many studies have addressed how engagement with political parties and political discussion on social media independently correlate with political participation, no research so far has addressed the interaction between these two factors. Looking at generic measures of political information and participation, Xenos and Moy (2007) found that the effects of political information acquired online on civic and political participation are contingent on political interest, with the highly interested experiencing greater participatory gains. However, their study predates the diffusion of social media, whose affordances, we have argued, entail qualitative changes in the relationship between information, expression, 
and participation. If political discussion on social media can act as a pathway towards greater engagement through serendipitous exposure to information, contact with weak ties, and enhanced self-expression, it could also lead to greater participatory gains among party nonmembers than members, thus narrowing the engagement gap between the two groups.

\section{Hypotheses}

We start from a holistic definition of "party-related political engagement" that is sensitive to the increasing integration of online and offline forms of political action (e.g. Oser et al. 2013) and hybridization of participatory repertoires (Chadwick 2007). Party-related engagement may be the purview of both "party campaigners" and "citizen campaigners". In the former case, party members use online and social media tools to help their parties. We therefore hypothesize that party membership will be positively correlated with party-related engagement (H1).

Political parties, however, are complex and varying structures that organize and recruit members differently across Western democracies. To account for some of these variations, we assess the relationship between party membership and party-related engagement in a comparative framework, an aspect that has been neglected in studies of social media and politics so far. We focus on Germany, Italy, and the United Kingdom because they are large Western democracies where we can identify meaningful systemic variance while keeping constant other characteristics—such as their political development, parliamentary form of government, and the fact that they voted simultaneously and with the same electoral system for the May 2014 European Parliament elections. Comparing Germany, Italy, and the United Kingdom allows us to identify country-level effects, to assess the robustness of our findings across different political systems, and to evaluate how the strength 
and inclusiveness of party organizations affects the relationship between party membership and engagement.

The characteristics of party organizations differ substantially across the three countries. British party membership declined dramatically over the last thirty years, as the main parties lost more than a million members (Van Biezen et al. 2012: 11). This downfall is not compensated by the recent surges in membership of the Scottish National Party (which had 93,000 members in January 2015), UK Independence Party $(39,000)$, and the Green Party (44,000; see House of Commons Library 2015). As a result, Britain ranks third to last among the 27 European Union member countries in terms of total party membership as a percentage of the electorate, with just above half a million members in total (Van Biezen et al. 2012: 5). ${ }^{2}$ Italian party membership, while historically higher than in Germany and the UK (Van Biezen et al. 2012), collapsed over the last decade, as the main center-right party (Forza Italia) all but neglected enrolling members and the main center-left party (Partito Democratico) saw its membership decline from one million upon its founding in 2007 to a reported 100,000 in 2014. ${ }^{3}$ The Five Star Movement, which polled a surprising second in the 2013 general elections and mostly organized online in its early days, does not formally enroll members, but allows those who register on the leader's blog to vote in primaries and internal referenda (Mosca et al. 2015). By contrast, German major parties still pursue the model of the Volkspartei, which is "mainly concerned with the integration of [...] at least a large share of citizens into the political decision-making process" (Jun 2011: 204) and thus demands that parties recruit substantial memberships. Although enrolment faltered over the last two decades, as of 2012 the six major German parties still enrolled a total of 1.28 million members. ${ }^{4}$ Moreover, German parties receive public funding on the basis of the contributions they raise from members, and thus have a particular incentive to recruit them. Finally, there are stark differences in the legitimacy of political parties in the three countries: in June 2014, 
$30 \%$ of Germans claimed to trust parties, whereas only $15 \%$ of British and $6 \%$ of Italian respondents did. ${ }^{5}$

We expect these differences to play a role in shaping the factors that lead party members to engage with party-related activities online due to both supply- and demandrelated mechanisms. On the supply side, better organized parties should be able to more effectively channel members' participation (Heidar 2006) and, conversely, less structured parties should be less capable of mobilizing their members. On the demand side, where parties are stronger, individuals aiming to influence politics should consider parties as more viable linkages to government and policymaking (Lawson 1980) and should thus be more likely to both become members and engage with party-related activities. By contrast, where party organizations are weaker, individuals eager to affect political outcomes should see limited value in party membership and may pursue their political goals by other means. Because German parties are comparatively stronger than Italian and British ones, we hypothesize that party membership will be more strongly correlated with party-related engagement in Germany than in Italy and the United Kingdom (H2).

As discussed above, informal political discussion on social media may also breed "citizen campaigners", that is, individuals who are not party members but who engage with party-related activities. We thus hypothesize that engagement with political discussions on social media will be positively correlated with party-related engagement, even after controlling for party membership and attitudes towards parties (H3).

Finally, we explore the possibility that informal political discussion on social media moderates the relationship between party membership and party-related engagement (H4). We expect that political discussions on social media reduce the distance between members and non-members in party-related engagement by facilitating informal political self-expression, 
which is a pathway to participation. Thus, we expect the sign of the interaction between discussion and membership to be negative.

\section{Data and Variables}

Data have been collected through three online surveys conducted in Germany, Italy, and the United Kingdom in the aftermath of the European Elections of 22-25 May 2014. The surveys were in the field between May 27-June 20. For each country, a sample $(N=1,750)$ representative of internet users aged 16-74 was constructed on the basis of online panels administered by IPSOS where respondents were offered non-monetary incentives to participate. Invitations were sent in each country until we achieved a sample that matched our target population on the following characteristics: age, gender, region of residence, occupational condition, and educational level. Response rates based on AAPOR's (2011) RR1 standard were $17 \%$ for Germany, $21.4 \%$ for Italy, and $20.1 \%$ for the United Kingdom. Because the quota sampling allowed us to achieve a very close fit between sample margins and population margins, no weighting was required for the German and Italian samples, whereas the UK data was weighted to ensure that sample margins matched population margins with respect to occupational condition. It is worth noting that in 2014 Eurostat estimated that $92 \%$ of Britons, $86 \%$ of Germans, but only $62 \%$ of Italians used the internet. ${ }^{6}$ As a result, even if our samples are representative of the populations with internet access in each country, the Italian sample is likely to deviate from the general voting-age population much more than the British and German ones. When assessing the validity of our data, it should be noted that nonprobability samples such as the one employed here tend to produce estimates of relationships between variables-which is what our hypotheses focus on-that are consistent with those obtained with probability samples (Pasek 2015). 
We measured our dependent variable—party-related engagement—as a combination of six different citizen activities that can be beneficial to political parties, listed below. In activities $\mathrm{A}$ and $\mathrm{B}$, individuals act as informal spokespersons for parties and candidates, in activities $\mathrm{C}$ and $\mathrm{D}$ they provide feedback, and in activities $\mathrm{E}$ and $\mathrm{F}$ they contribute time and money. ${ }^{7}$

A. Encouraging other people to vote for a party or candidate on social media (performed by $9.9 \%$ of German respondents, 15.5\% of the Italian ones, and $17.2 \%$ of the UK ones).

B. Encouraging other people to vote for a party or candidate by sending an email (Germany 6\%, Italy 12.5\%, UK 13.4\%).

C. Commenting on a post of, or sending a message to, a party or candidate on social media (Germany 8.7\%, Italy 18.5\%, UK 14.3\%).

D. Sending an email to a party or politician (Germany $10.2 \%$, Italy $15.9 \%$, UK $17.9 \%)$.

E. Financing a political party, candidate, or campaign (Germany 5\%, Italy $6.7 \%$, UK 7.1\%).

F. Participating in the activities of a political party (Germany $8.6 \%$, Italy $11.5 \%$, UK $9.3 \%)$.

The data show notable integration across these different endeavors: Cronbach's alpha across the six items is .806 in Germany, .765 in Italy, and .821 in the UK (.799 when combining data from all three countries). The average values of the index, which ranges from 0 to 6 , are .48 in Germany, .83 in Italy, and .80 in the United Kingdom, and the difference between Germany and the other two countries is statistically significant at $p=.000$ based on independent samples t-tests. Although this is only a descriptive finding, it is interesting in itself because 
Germany also stands out as the country where parties are organizationally stronger and more trusted by citizens. We return to this point below.

We test our hypotheses through multivariate Poisson regressions, which are appropriate when the dependent variable is a count variable. We ran three separate regressions (incrementally including the interaction terms we considered) to estimate the value of the index of party-related engagement. Our key independent variables are party membership ${ }^{8}$ (which allows us to test $\mathrm{H} 1$ ), the interaction between party membership and country (with Germany as reference category, allowing us to test H2), political discussion on social media ${ }^{9}$ (which allows us to test H3), and the interaction between party membership and political discussion on social media (mean-centred to mitigate risks of multicollinearity, allowing us to test H4). Since some of the questions employed to build the dependent variable, as well as those dealing with political discussion on social media, were only asked to those respondents who claimed to have a profile on at least one major social networking site (82.1\% of German respondents, 88\% of Italians, and $85.9 \%$ of British ones), our regression models only include - and should be generalized to-social media users. The models control for gender, age, education, income, ${ }^{10}$ trust in parties, interest in politics, political efficacy, ${ }^{11}$ the country of the respondent (with Germany as reference category), and exposure to political news on different media channels. All non-dichotomous independent and control variables have been normalized to range between 0 and 1 to facilitate comparisons across coefficients.

\section{Findings}

Table 1 shows the results of Poisson regression models predicting the value of the index of party-related engagement. The pseudo- $\mathrm{R}^{2}$ coefficients at the bottom of the table suggest that the models fit the data satisfactorily, and increasingly so as interactions are included.

TABLE 1 ABOUT HERE 
As shown by the positive and statistically significant correlations between party membership and party-related engagement across all three models, party members engage in substantially more activities than the rest of the sample, thus confirming H1. This is true in all three countries considered, but, as model 1 shows, the relationship is significantly stronger in Germany. Thus, our H2 predicting a stronger correlation between party membership and party-related engagement in Germany than in Italy and the United Kingdom is also confirmed.

Party-related engagement, however, is not solely the purview of party members, as citizen campaigners also substantially contribute to these activities. This is shown by the fact that the coefficient for political discussion on social media is positive and statistically significant, thus supporting H3. It should be kept in mind that the models control for party membership, political efficacy (which is positively and significantly associated with partyrelated engagement in models 1 and 2), interest in politics (which is positively and significantly associated with party-related engagement in all three models), and trust in parties. This means that political discussion on social media can provide a pathway to partyrelated engagement even after relevant political attitudes are taken into account.

Finally, model 2 shows that political discussion on social media moderates the relationship between party membership and party-related engagement, as predicted by H4. The coefficient is statistically significant, and the sign is negative, which indicates that the strength of the relationship between membership and engagement decreases as the intensity with which one discusses politics on social media increases. For instance, a typical ${ }^{12}$ Italian respondent who is a party member and discusses politics on social media one standard deviation less than average is predicted to participate in slightly more than one of the six party-related engagement activities we tested (1.22 on a $0-6$ scale), which grows to about two activities (2.04) if political discussion on social media increases to one standard deviation above the mean. By contrast, a typical respondent who is not a party member and who 
discusses politics less than average is predicted to not engage in any party-related endeavor at all (with the index equaling .19), but when political discussion on social media is raised to one standard deviation above average, the respondent is predicted to engage in close to one party-related activity (.84). The numerical differences are substantial一the value of the index grows by $332 \%$ among non-members as opposed to $67 \%$ among members-but the substantive implications are equally compelling. Higher levels of political discussion on social media make already active party members even more active, as they move from one to two predicted activities, but non-members move from political inaction (with effectively zero predicted activities) to at least some level of engagement (approximating one predicted activity). In sum, political discussion on social media is associated with increased participation among both already active members and otherwise inactive non-members.

Further evidence of these dynamics can be seen in the country coefficients in model 2 (see again Table 1). The positive and significant coefficients for Italian and UK respondents indicate that party non-members in Italy and the UK engage in a significantly higher number of party-related activities than party non-members in Germany. In other words, where parties are weaker and less legitimate, those who want to get involved with politics are more likely to do so as citizen campaigners than as party campaigners. Recalling that German respondents were overall substantially less engaged than British and Italian ones (as shown by both the average values of the index and the positive and significant coefficients for the Italy and UK dummy variables in the multivariate models), the greater ability of German parties to engage their members seems to be an aggregate double-edged sword. The better organized parties are, and the better they structure their members' activities on social media, the less they attract participants from outside their ranks.

Before discussing the main implications of our findings, we acknowledge that they are subject to some degree of endogeneity due to the cross-sectional nature of our data, which do 
not warrant strong causal claims, even though our hypotheses focused on correlations rather than causal effects. Secondly, our surveys were administered in the aftermath of European elections, which have specific characteristics that are not necessarily present in general elections. Thirdly, we compared two countries with similarly high levels of internet accessGermany and the UK-with another-Italy—with lower levels of access, which suggests caution when generalizing these findings beyond the populations of interest. Because citizens with internet access tend to have higher socio-economic status than those without internet access, and because socio-economic status also predicts political engagement, it is plausible that our sample selection strategy may have led us to recruit Italian respondents who, whilst representative of the Italian online population, are generally more engaged in politics than they would be if levels of internet use in Italy were similar to those in Britain and Germany.

Finally, although we see great promise in comparative research on social media and politics, it is difficult to disentangle causal patterns related to contextual factors while studying only three countries at a single point in time. We theorized that the strength and legitimacy of party organizations shape the relationship between party membership and party-related engagement via both supply- and demand-related mechanisms. However, other systemic characteristics, such as candidate and leader selection methods and campaign finance regulations, may also play a role (see Anstead and Chadwick 2009). Primaries and direct leadership elections incentivize outsiders and their supporters to experiment with digital tools, thus mobilizing citizen campaigners. In the countries we studied, however, there is no cross-party convergence (as there is between the Democratic and Republican parties in the US) in the ways leaders and candidates are selected, so this factor may explain differences between parties rather than countries. Campaign finance regulation also differs across the countries we studied, with German parties enjoying generous public funding, British parties mostly relying on unlimited private donations, and Italian parties currently benefiting from 
residual public funding but also facing increasing pressure to tap uncapped private contributions (Vaccari 2013). However, none of these countries limit individual donations, which Anstead and Chadwick (2009) show incentivize US campaigns to recruit large numbers of small online donors, many of whom then become citizen campaigners.

\section{Conclusions}

In this study we have questioned two common narratives about political parties and their relationship with the internet—-that parties are facing an unstoppable decline and that digital media contribute to this decline because they distract citizens or they only engage activists who are already engaged. By contrast, we have shown that digital media should be considered part of the solution rather than the problem of party crisis. The fact that party activists are more likely to engage with parties' social media presence is just one half of the story-the other is that activists use these platforms to, among other things, distribute party messages beyond supporters. Non-members who engage in informal political discussions online also perform online activities that are valuable for parties. The low-threshold nature of the endeavors we conceptualized as comprising party-related engagement makes them appealing across a broader constituency than the narrower constituency of party members. Even if, on average, an individual "party campaigner" provides more activities and resources than a "citizen campaigner," in most populations there are likely to be many more of the latter than the former, and so the aggregate contributions of citizen campaigners may conceivably approximate, or even exceed, the aggregate contributions of party campaigners. Social media can thus help parties mobilize support and gather feedback from both their core membership base and a wider subset of engaged citizens who are not committed to parties but enjoy discussing politics on social media. Not only do social media contribute to hybridizing repertoires of party activism, but they are also promoting a hybridization of party activists, 
bringing together older and newer types of participants who may have different views of party engagement and different reasons for taking part in it.

These developments suggest avenues for future research investigating, for instance, the strategies parties employ to channel citizen campaigners towards shared goals, the extent to which citizen campaigners engage in grassroots party politics, and whether internal power relationships are bound to be restructured as a result of their influx. If parties persist in their attempt to cajole sympathizers to become more involved in their activities and decisionmaking (Scarrow 2015), their targeting of citizen campaigners may result in new and more inclusive participatory mechanisms, with important implications for party internal dynamics. For instance, the French Socialist Party in 2007 introduced online membership at a €20 discounted price to promote participation in the primaries to select its Presidential candidate. In 2014 the UK Labour party created the category of "registered supporters", who acquired the right to vote for the party leader by paying a one-off minimum fee of $£ 3$ on the party website. Outsider parties such as the Spanish Podemos and the Italian Five Star Movement have adopted even more radical strategies, allowing members to enrol online for free. Parties are trying to harness digital media in a hybrid mix with their efforts on the ground to enlist citizen campaigners who can either rejuvenate their core activist bases or create new constituencies of support.

This qualitative and quantitative expansion of party membership could lead to potential tensions in the balance of power within organizations, as party elites may be more at ease with their ordinary rank-and-file members than with citizen campaigners whose behaviours are likely to be more difficult to predict and control. To avoid these risks, parties can be expected to continue pursuing a strategy of "controlled interactivity" (Stromer-Galley 2014) that allows them to maintain power over key decisions while delegating and diffusing some aspects of their execution. However, when it comes to high-profile internal decisions, 
the party establishment may find it difficult to contain the forces set in motion by the combination of digital affordances for supporter engagement and the opening up of political opportunities.

The complex interplay between older and newer modes of party-related engagement, and its implications for internal party politics, were in full display in the 2015 UK Labour party leadership election, where as many as 105,600 (out of a total 112,000 online-enrolled) registered supporters voted, little less than half the 245,675 (out of a total 292,000) full members. Jeremy Corbyn, a textbook party outsider who had been a backbencher for all his 32 years in Parliament, was elected leader with the support of an overwhelming 83.8\% of registered supporters, as opposed to $49.6 \%$ among full members. ${ }^{13}$ The success of the Corbyn campaign was based on a hybrid mix of traditional volunteering, mostly engineered by trade unions, and digitally enabled strategies to recruit registered supporters and distribute the campaign message on social media. To some degree, the findings shown here suggest that already in 2014 there was a reservoir of citizen campaigners who were not party members but were ready to participate in party-related activities, which the Corbyn campaign tapped into.

The disruptive potential of citizen-campaigners on internal party politics may be contingent on the political opportunities provided by institutional arrangements. These opportunities were present in the UK Labour party's 2015 leadership election, and may also exist in some Italian parties—such as the Democratic Party and the Five Star Movement, which to some degree recruit supporters online and allow them some influence over internal decisions. However, other parties in the same countries, as well as all of the main German parties, do not provide substantial opportunities for non-members to influence internal decisions, which may limit the influence of online-mobilized outsider activists. 
Although Western parties are facing monumental challenges, social media are not hastening their decline-quite to the contrary, they both help new digital foot soldiers to emerge and allow existing members to expand their repertoires. That said, our data measure (self-reported) involvement with party-related activities, but do not address whether such activities were conducted in accordance with party goals and consistently with core party messages. It is an open question whether both party campaigners and citizen campaigners are reliable "agents" to their party "principals," as highlighted by Enos and Hersh (2015). Relatedly, our findings speak to a growing body of research (Nielsen 2012) showing that party campaigning on the ground no longer depends solely on grassroots organizing and coordination in physical settings, but also on the integration of online and offline tools and endeavors. Since the background, motivations, and skills of party campaigners are likely to be different from those of citizen campaigners, coordinating them across both digital and physical environments could be increasingly challenging, even if facilitated by data-driven computational management (Kreiss 2012).

Finally, although the processes discussed in this research are developing in all the three countries we studied, and on theoretical grounds can be expected to be reproduced across most Western democracies, the quality and quantity of such developments vary in accordance with the systemic features of each country. In particular, the strength of party organizations has emerged as a potentially important condition for the broadening of online activities among both members and supporters. Digital media may rejuvenate the relationship between parties and their members in the contexts where this is less needed (such as Germany), while appealing more to non-members in contexts where parties have suffered steeper organizational declines (such as Italy and the UK). The extent to which social media deepen engagement among members and broaden it among non-members is path-dependent 
on the organizational legacies of the parties themselves, while at the same time being an important part of the story of how they can be revitalized.

\section{Acknowledgments}

This research was supported by the Italian Ministry of Education "Future in Research 2012" initiative (project code RBFR12BKZH) for the project titled "Building Inclusive Societies and a Global Europe Online: Political Information and Participation on Social Media in Comparative Perspective" (http://www.webpoleu.net). We thank the special issue editors and the anonymous reviewers for their useful comments. In accordance with Italian academic conventions, we specify that Cristian Vaccari wrote the sections titled "Party-Related Engagement Among and Beyond Party Members", "Findings" and "Conclusions" and Augusto Valeriani wrote the introductory section and the sections titled "Data and Variables" and "Hypotheses". 


\section{References}

Anstead, Nick and Andrew Chadwick. 2009. "Parties, Election Campaigning and the Internet: Toward a Comparative Institutional Approach." In The Routledge Handbook of Internet Politics, ed. Andrew Chadwick and Philip N. Howard, 56-71, London, New York: Routledge.

Bawn, Kathleen, Martin Cohen, David Karol, Seth Masket, Hans Noel, and John Zaller. 2012. "A theory of political parties: Groups, policy demands and nominations in American politics." Perspectives on Politics 10(3): 571-597.

Blais, André. 2007. "Turnout in Elections." In The Oxford Handbook of Political Behavior, ed. Russell J. Dalton and Hans-Dieter Klingemann, 621-635. Oxford: Oxford University Press.

Chadwick, Andrew. 2007. "Digital network repertoires and organizational hybridity." Political Communication 24 (3): 283-301.

Chadwick, Andrew. 2009. "Web 2.0: New Challenges for the Study of E-Democracy in an Era of Informational Exuberance." I/S: Journal of Law and Policy for the Information Society 5 (1): $9-41$.

Coleman, Stephen. 2005. "The Lonely Citizen: Indirect Representation in an Age of Networks." Political Communication 22 (2): 197-214.

Dalton, Russell J. 1984. “Cognitive mobilization and partisan dealignment in advanced industrial democracies." The Journal of Politics 46 (1): 264-284.

Edwards, Arthur 2006. "ICT strategies of democratic intermediaries: A view on the political system in the digital age." Information Polity 11 (2): 163-176.

Enos, Ryan D. and Eitan D. Hersh. 2015. “Party Activists as Campaign Advertisers: The Ground Campaign as a Principal-Agent Problem." American Political Science Review 109 (02): 252-278. doi:10.1017/S0003055415000064 
Gibson, Rachel. 2015. "Party change, social media and the rise of 'citizen-initiated' campaigning." Party Politics 21 (2): 183-197.

Gibson, Rachel and Marta Cantijoch. 2013. “Conceptualizing and measuring participation in the age of the internet: Is online political engagement really different to offline?" The Journal of Politics 75 (3): 701-716.

Gil de Zúñiga, Homero, Logan Molyneux and P. Zheng. 2014. “Social Media, Political Expression, and Political Participation: Panel Analysis of Lagged and Concurrent Relationships." Journal of Communication 64 (4): 612-634.

Gil de Zúñiga, Homero and Sebastiàn Valenzuela. 2011. "The mediating path to a stronger citizenship: Online and offline networks, weak ties and civic engagement." Communication Research 38 (3): 397-421.

Heaney, Michael. T. and Fabio Rojas. 2015. Party in the Street: The Antiwar Movement and the Democratic Party After 9/11. New York: Cambridge University Press.

Heidar, Knut. 2006. "Party membership and participation." In Handbook of Party Politics, ed. Richard Katz and William Crotty,, 301-315, London: Sage Publications.

House of Commons Library. 2015. Membership of UK Political Parties, 30 January 2015, $\begin{array}{llll}\text { URL } & \text { (accessed } & 26 & \text { May }\end{array}$ http://researchbriefings.parliament.uk/ResearchBriefing/Summary/SN05125

Jackson, Nigel A. and Darren G. Lilleker. 2009. “Building an Architecture of Participation? Political Parties and Web 2.0 in Britain." Journal of Information Technology \& Politics 6 (3-4): 232-250.

Jun, Uwe. 2011. "Volksparteien under Pressure: Challenges and Adaptation." German Politics 20 (1): 200-222. 
King, Gary, James Honaker, Anne Joseph and Kenneth Scheve. 2001. "Analyzing Incomplete Political Science Data: An Alternative Algorithm for Multiple Imputation." American Political Science Review 95 (1): 49-69.

Kirchheimer, Otto. 1966. "The Transformation of the Western European Party Systems.” In Political Parties and Political Development, ed. Joseph La Polombara and Myron Weiner, 177-200, Princeton: Princeton University Press.

Kreiss, Daniel. 2012. Taking our country back: The crafting of networked politics from Howard Dean to Barack Obama. Oxford: Oxford University Press.

Kwak Nojin, Ann Williams, Xiaoru Wang and Hoon Lee. 2005. “Talking politics and engaging politics: An examination of the interactive relationships between structural features of political talk and discussion engagement." Communication Research 32: 87-111.

Lawson, Kay (ed.). 1980. Political parties and linkage: A comparative perspective. New Haven: Yale University Press.

Mair, Peter 1995. "Political parties, popular legitimacy and public privilege." West European Politics, 18 (3): 40-57.

Margetts, Helen 2006. "Cyber Parties." In Handbook of Party Politics, ed. Richard S. Katz and William Crotty, 528-535, London: Sage Publications.

Margolis, Michael, and David K. Resnick. 2000. Politics as Usual: The Cyberspace "Revolution." London: Sage.

Mosca, Lorenzo, Cristian Vaccari and Augusto Valeriani. 2015. An Internet-Fuelled Party? The Five Star Movement and the Web. In Beppe Grillo's Five Star Movement: Organisation, Communication and ideology, ed. Filippo Tronconi, 127-152. Farnham: Ashgate.

Nielsen, Rasmus Kleis. 2012. Ground wars: Personalized communication in political campaigns. Princeton: Princeton University Press. 
Norris, Pippa. 2003. "Preaching to the Converted? Pluralism, Participation and Party Websites." Party Politics 9 (1): 21-45.

Norris, Pippa. 2006. “Recruitment.” In Handbook of Party Politics, ed. Richard S. Katz and William Crotty, 89-108. London: Sage.

Norris, Pippa and John Curtice. 2008. “Getting the message out: a two-step model of the role of the internet in campaign communication flows during the 2005 British general election." Journal of Information Technology \& Politics 4 (4): 3-13.

Oser, Jennifer, Marc Hooghe and Sofie Marien. 2013. "Is online participation distinct from offline participation? A latent class analysis of participation types and their stratification." Political Research Quarterly 66 (1): 91-101.

Panebianco, Angelo. 1988. Political parties: Organization and Power. Cambridge: Cambridge University Press.

Pasek, Josh. 2015. "When will Nonprobability Surveys Mirror Probability Surveys? Considering Types of Inference and Weighting Strategies as Criteria for Correspondence." International Journal of Public Opinion Research, doi:10.1093/ijpor/edv016

Rojas, Hernando and Eulalla Puig-i-Abril. 2009. “Mobilizers mobilized: Information, expression, mobilization and participation in the digital age." Journal of Computer-Mediated Communication 14 (4): 902-927.

Scarrow, Susan. 2015. Beyond party members: Changing approaches to partisan mobilization. Oxford: Oxford University Press.

Schlozman, Kay Lehman, Verba, Sidney, and Henry E. Brady. 2010. "Weapon of the strong? Participatory inequality and the Internet." Perspectives on Politics 8 (2): 487-509.

Stromer-Galley, Jennifer 2014. Presidential campaigning in the Internet age. Oxford: Oxford University Press. 
Vaccari, Cristian 2013. Digital Politics in Western Democracies: A Comparative Study. Baltimore: Johns Hopkins University Press.

Vaccari, Cristian, Augusto Valeriani, Pablo Barberá, Rich Bonneau, John T. Jost, Jonathan Nagler and Joshua A. Tucker. 2015. "Political Expression and Action on Social Media: Exploring the Relationship Between Lower-and Higher-Threshold Political Activities Among Twitter Users in Italy." Journal of Computer-Mediated Communication, doi: $10.1111 /$ jcc4.12108

Valeriani, Augusto and Cristian Vaccari. 2015. “Accidental exposure to politics on social media as online participation equalizer in Germany, Italy, and the United Kingdom." New Media \& Society, doi: 10.1177/1461444815616223

Van Biezen, Ingrid, Peter Mair and Thomas Poguntke. 2012. “Going, Going ... Gone? The decline of party membership in contemporary Europe." European Journal of Political Research 51 (1): 24-56.

Whiteley, Paul and Seyd, Patrick 2003. "How to win a landslide by really trying: the effects of local campaigning on voting in the 1997 British general election." Electoral Studies 22 (2): 301-324.

Whiteley, Paul (2011). Is the party over? The decline of party activism and membership across the democratic world. Party Politics 17 (1): 21-44.

Wojcieszak, Magdalena E. and Diana C. Mutz. 2009. “Online Groups and Political Discourse: Do Online Discussion Spaces Facilitate Exposure to Political Disagreement?" Journal of Communication 59 (1): 40-56.

Wright, Scott. 2012. "Politics as usual? Revolution, normalization and a new agenda for online deliberation." New Media \& Society 14 (2): 244-261.

Xenos, Michael and Patricia Moy. 2007. “Direct and differential effects of the Internet on political and civic engagement." Journal of Communication 57 (4): 704-718. 
Table 1 - Estimated coefficients for party-related engagement (0-6 index)

\begin{tabular}{|c|c|c|c|c|c|c|}
\hline & \multicolumn{2}{|c|}{ Model 0} & \multicolumn{2}{|c|}{ Model 1} & \multicolumn{2}{|c|}{ Model 2} \\
\hline & Coefficient & S.E. & Coefficient & S.E. & Coefficient & S.E. \\
\hline Party member & $.880^{* * *}$ & .055 & $1.206^{* * *}$ & .105 & $1.752^{* * *}$ & .104 \\
\hline Political discussion on social media & $2.121^{* * *}$ & .102 & $2.100^{* * *}$ & .102 & $2.740^{* * *}$ & .110 \\
\hline \multicolumn{7}{|c|}{ Country*Party member (Germany=reference) } \\
\hline Italy*Party member & / & / & $-.444^{* * *}$ & .118 & $-.380 * * *$ & .111 \\
\hline UK*Party member & / & / & $-.382^{* *}$ & .125 & $-.329 * *$ & .116 \\
\hline Political discussion*Party member & / & / & / & / & $-1.782^{* * *}$ & .165 \\
\hline \multicolumn{7}{|l|}{ Country (Germany=reference) } \\
\hline Italy & $.410^{* * *}$ & .062 & $.586^{* * *}$ & .083 & $.542^{* * *}$ & .084 \\
\hline United Kingdom & $.283^{* * *}$ & .063 & $.439 * * *$ & .089 & $.442^{* *}$ & .089 \\
\hline \multicolumn{7}{|l|}{ Sources of political information } \\
\hline Internet & $.751^{* * *}$ & .132 & $.744^{* * *}$ & .133 & $.709 * * *$ & .131 \\
\hline Newspapers & $.426^{* * *}$ & .096 & $.415^{* * *}$ & .096 & $.382^{* *}$ & .094 \\
\hline Television & -.079 & .119 & -.073 & .119 & -.084 & .118 \\
\hline Radio & .180 & .094 & .194 & .095 & $.227 *$ & .093 \\
\hline Political efficacy & .792 & .121 & $.788^{* * *}$ & .120 & $.637^{* * *}$ & .114 \\
\hline Interest in politics & $.369 * * *$ & .103 & $.377^{* * *}$ & .102 & $.353^{* * *}$ & .095 \\
\hline Trust in parties & -.114 & .073 & -.088 & .074 & .024 & .071 \\
\hline Gender (male) & $.090^{*}$ & .045 & $.094^{*}$ & .045 & .073 & .042 \\
\hline Age & -.114 & .104 & -.116 & .102 & -.123 & .099 \\
\hline Education & .016 & .066 & .018 & .066 & -.009 & .062 \\
\hline Income & -.045 & .083 & -.048 & .081 & -.024 & .076 \\
\hline Constant & $-2.984^{* * *}$ & .124 & $-3.125^{* * *}$ & .133 & $-2.598^{* * *}$ & .136 \\
\hline$N$ & \multicolumn{2}{|l|}{3869} & \multicolumn{2}{|r|}{3869} & 3869 & \\
\hline Pseudo- $\mathrm{R}^{2}$ & .391 & & & .393 & .406 & \\
\hline Likelihood ratio $\chi^{2}$ & 3892.983 & & & 3911.868 & 4051.167 & \\
\hline
\end{tabular}

Note: All non-dichotomous independent variables have been normalized in a range between 0 and 1 . The variable expressing political discussion on social media is centered around its mean in Model 2. Dummy variables identifying missing observations for income and political efficacy have been omitted from the table; see notes 10 and 11 for details. ${ }^{* * *} \mathrm{p} \leq .001^{* *} \mathrm{p} \leq .01^{*} \mathrm{p} \leq .05$ 
${ }^{1}$ Retrieved from http://ec.europa.eu/public_opinion/cf/index.cfm (accessed 30 June 2014). ${ }^{2}$ In 2015, membership of the Labour party surged as a result of two phenomena. First, the party recruited more than 100,000 registered supporters (a development we discuss in the concluding section). Secondly, following the election of Jeremy Corbyn as leader, Labour nearly doubled its membership from 201,293 before the 2015 general election to 388,407 on 10 January 2016 (see http://www.theguardian.com/politics/2016/jan/13/revealed-howjeremy-corbyn-has-reshaped-the-labour-party, accessed 15 January 2016). The Corbyn-led surge in Labour membership can actually be explained by our findings, as discussed in the conclusions.

${ }^{3}$ See http://www.repubblica.it/politica/2014/10/03/news/pd_crollo_iscrizioni-97212221/ (accessed 7 October 2014).

${ }^{4}$ See http://www.polsoz.fuberlin.de/polwiss/forschung/systeme/empsoz/schriften/Arbeitshefte/ahosz19.pdf (accessed 14 October 2014).

${ }^{5}$ Data retrieved from http://ec.europa.eu/public_opinion/index_en.htm (accessed 22 June 2015).

${ }^{6}$ See http://ec.europa.eu/eurostat/statisticsexplained/index.php/Internet_and_cloud_services_-_statistics_on_the_use_by_individuals (accessed 21 December 2015).

${ }^{7}$ All items were introduced by a question asking respondents whether they had performed each of the activities "in the past 12 months". Response modes were "yes", "no", and "can't remember". Our index is a count of all the "yes" answers to each item. 
${ }^{8}$ We measure this variable through the question: "Over the past 12 months, have you been member of any political party? Yes; No; Don't remember". We coded the values in the same way as for the variables included in the index of party-related engagement. Party members were $10.1 \%$ in the Italian, $6.7 \%$ in the German and $10.2 \%$ in British sample.

${ }^{9}$ We measure this variable through two separate questions, one for posting and another for reading political messages on social media: "Thinking about everything you have posted recently on social media, such as status updates, comments, replies, retweets, and links, about how much of what you have posted is related to politics, political issues or the 2014 elections?" and "How about the messages you have recently received from people you follow or are in contact with on social media? How many of them are related to politics, political issues or the 2014 elections?" Respondents could answer both questions by indicating a number between 0 (none) and 10 (all). After normalizing the resulting variable in a range between 0 and 1 the country values are as follows. Germany: mean .20, median .05, SD .25. Italy: mean .31, median .25, SD .27. UK: mean .28, median .20, SD .27.

${ }^{10}$ Because our income variable had 831 missing values, rather than introducing bias through listwise deletion (King et al. 2001), we mean-replace these missing values and add a dummy variable to the analysis identifying these cases. With this set-up, the coefficient on any given variable with missing data should be interpreted as the effect of that variable on our dependent variable for the cases for which we have observations of the independent variable in question; we thank Josh Tucker for suggesting this approach.

11 This variable has been created by recoding and aggregating answers to three different questions all introduced by the phrase: "How much do you agree with these statements?". The statements were: "People like me have no influence on what the government does"; "Politicians are interested in what people like me think"; "Sometimes politics is so 
complicated that you cannot understand what is happening". The aggregate variable had 381 missing values because a substantial number of respondents answered "don't know" to at least one question. We performed the same procedure as adopted for income to ensure that these respondents are still included in our analysis (see previous note).

12 The values for the effect size estimates reported in this paragraph are calculated on the basis of Model 2 in Table 1 by setting all variables besides party membership and political discussion to their mean (for ordinal- and interval-level variables) and mode (for dichotomous variables) across the pooled sample.

${ }^{13}$ See http://www.labour.org.uk/blog/entry/results-of-the-labour-leadership-and-deputyleadership-election (accessed 22 December 2015). 